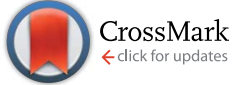

Cite this: RSC Adv., 2015, 5, 48983

Received 12th February 2015

Accepted 26th May 2015

DOI: $10.1039 / \mathrm{c} 5 \mathrm{ra02750k}$

www.rsc.org/advances

\section{Synthesis of $\mathrm{g}-\mathrm{C}_{3} \mathrm{~N}_{4} / \mathrm{Bi}_{2} \mathrm{O}_{3} / \mathrm{TiO}_{2}$ composite nanotubes: enhanced activity under visible light irradiation and improved photoelectrochemical activity $\dagger$}

\author{
Yi Zhang, ${ }^{\star a b}$ Jiani Lu, ${ }^{a}$ Michael R. Hoffmann, ${ }^{b}$ Qiang Wang, ${ }^{a}$ Yanqing Cong, ${ }^{a}$ Qi Wang ${ }^{a}$ \\ and Huan $\mathrm{Jin}^{\mathrm{a}}$
}

g- $\mathrm{C}_{3} \mathrm{~N}_{4}$ and $\mathrm{Bi}_{2} \mathrm{O}_{3}$ were successfully incorporated into $\mathrm{TiO}_{2}$ nanotubes $\left(\mathrm{TiO}_{2}-\mathrm{NT}\right)$ to produce a composite nanotube material designated as $\mathrm{g}-\mathrm{C}_{3} \mathrm{~N}_{4} / \mathrm{Bi}_{2} \mathrm{O}_{3} / \mathrm{TiO}_{2}$. The photoelectrochemical (PEC) activity under visible light irradiation with respect to bleaching of methylene blue (MB) and degradation of phenol were determined. The UV-vis absorption spectrum of the composite material, g- $\mathrm{C}_{3} \mathrm{~N}_{4} / \mathrm{Bi}_{2} \mathrm{O}_{3} / \mathrm{TiO}_{2}-\mathrm{NT}$, was red-shifted toward a narrower band gap energy $\left(E_{\mathrm{g}}\right)$. The valence band (VB) of g- $\mathrm{C}_{3} \mathrm{~N}_{4} / \mathrm{Bi}_{2} \mathrm{O}_{3} / \mathrm{TiO}_{2}-\mathrm{NT}$ was shifted to a more positive potential resulting in an increased driving force for water oxidation. The photocurrent generated by $\mathrm{g}-\mathrm{C}_{3} \mathrm{~N}_{4} / \mathrm{Bi}_{2} \mathrm{O}_{3} / \mathrm{TiO}_{2}-\mathrm{NTs}$ was approximately 15 times higher and the incident photon-to-current efficiency (IPCE at $\lambda=400 \mathrm{~nm}$ ) was higher than that of the naked $\mathrm{TiO}_{2}-\mathrm{NTs}$. This response is attributed to increasing the lifetimes of photo-generated electron-hole pairs. A significantly higher PEC response in terms of the bleaching of $\mathrm{MB}$ was observed on $\mathrm{g}-\mathrm{C}_{3} \mathrm{~N}_{4} / \mathrm{Bi}_{2} \mathrm{O}_{3} / \mathrm{TiO}_{2}-\mathrm{NT}$. The roles of improved charge separation and subsequent higher electron-transfer efficiencies for in $\mathrm{g}-\mathrm{C}_{3} \mathrm{~N}_{4} / \mathrm{Bi}_{2} \mathrm{O}_{3} /$ $\mathrm{TiO}_{2}-\mathrm{NT}$ electrodes were examined.

\section{Introduction}

Semiconductor photocatalysis has been extensively explored for a variety of environmental control applications ${ }^{1-3}$ and for solar energy conversion in terms of photocatalytic water-splitting ${ }^{\mathbf{4 , 5}}$ and artificial photosynthesis including $\mathrm{CO}_{2}$ reduction to hydrocarbon fuels. ${ }^{6}$ Photoelectrochemical (PEC) activity under an applied potential bias was applied for splitting water or degradation of environmental pollutants. Since $43 \%$ of incoming solar radiation is within the visible region, improving solar conversion efficiency over this region is important. ${ }^{7}$ For large-scale applications, sustained and in-depth attention has been paid to $\mathrm{TiO}_{2}$ because the cost is low, stability is excellent and band edge potential is suitable ${ }^{\mathbf{8} 9}$ However, since UV light ( $4 \%$ of the solar spectrum) at $\lambda \leq 385 \mathrm{~nm}$ is required to activate anatase $\mathrm{TiO}_{2}$, the potential practical applications are limited. ${ }^{\mathbf{1 0}}$ The modified $\mathrm{TiO}_{2}$ has been investigated to improve the photocatalytic activity induced by visible light. For instance, doping $\mathrm{TiO}_{2}$ with metal ions ${ }^{11,12}$ or nonmetal ions ${ }^{13,14}$ have been

${ }^{a}$ School of Environmental Science and Engineering, Zhejiang Gongshang University, Hangzhou 310018, China. E-mail: zhangyi@zjgsu.edu.cn; Fax: +86-571-28008215; Tel: $+86-571-28878218$

${ }^{b}$ Linde-Robinson Laboratories, California Institute of Technology, Pasadena, CA 91125, USA

$\uparrow$ Electronic supplementary information (ESI) available. See DOI: $10.1039 / \mathrm{c} 5 \mathrm{ra02750k}$ employed. Moreover, some non-oxide photocatalysts (e.g., metal sulfides, (oxy) nitrides and oxysulfides) $)^{15,16}$ and various metal complexes (e.g., $\mathrm{Pt}, \mathrm{Au}$ or $\mathrm{Ag})^{17}$ are quite active under visible light irradiation. However, rapid electron-hole recombination, reduced stability, and high costs of production of the doped metal oxides prevent their larger-scale practical applications.

Recently, compositing with two or more different substances together on $\mathrm{TiO}_{2}$ has drawn increasing attention to researchers and been confirmed to be an effective approach. Polypyrroledecorated $\mathrm{Ag}-\mathrm{TiO}_{2}$ nanofibers, ${ }^{18} \mathrm{Bi}_{2} \mathrm{O}_{3} / \mathrm{Bi}_{4} \mathrm{Ti}_{3} \mathrm{O}_{12} / \mathrm{TiO}_{2}$ nanobelts, ${ }^{19} \mathrm{Bi}_{2} \mathrm{O}_{3} / \mathrm{TiO}_{2} /$ graphene composite systems ${ }^{20}$ have shown promise for achieving higher visible light photocatalytic activity. In addition, electrochemistry improving the photocatalysis system also has been developed. $\mathrm{N}$ and $\mathrm{S}$ co-doped into $\mathrm{TiO}_{2}$ nanotube array films ${ }^{21}$ and $\mathrm{B}$ and $\mathrm{P}$ co-doped $\mathrm{TiO}_{2}$ nanotube arrays $^{22}$ exhibited excellent PEC properties and photocatalytic activities than undoped $\mathrm{TiO}_{2}$.

Recently, graphitic carbon nitride $\left(\mathrm{g}-\mathrm{C}_{3} \mathrm{~N}_{4}\right)$ was studied having capable of oxidation of pollutants under visible light irradiation. ${ }^{23,24}$ Moreover, g- $\mathrm{C}_{3} \mathrm{~N}_{4}$ has high chemical and thermal stability with narrower band gap energy $\left(E_{\mathrm{g}}\right)$ of $2.7 \mathrm{eV}$ (ref. 23) than $\mathrm{TiO}_{2}$. Other researchers have synthesized $\mathrm{TiO}_{2}$ modified with $\mathrm{g}-\mathrm{C}_{3} \mathrm{~N}_{4}$ by chemical vapor deposition ${ }^{25}$ or electrodeposition methods ${ }^{\mathbf{2 6}}$ to obtain materials that were photoelectrocatalytically active under visible light illumination. $\mathrm{Bi}_{2} \mathrm{O}_{3}$ is also being explored as a potentially useful photocatalyst due 
to its lower bandgap energy $(2.8 \mathrm{eV})$ and beneficial electrical properties. ${ }^{27} \mathrm{Bi}_{2} \mathrm{O}_{3}$ has also been combined with $\mathrm{TiO}_{2}$ for improved visible light activity. ${ }^{28,29}$ A multi-material composite incorporating $\mathrm{g}-\mathrm{C}_{3} \mathrm{~N}_{4}$ and $\mathrm{Bi}_{2} \mathrm{O}_{3}$ into titanium dioxide nanotubes was prepared and tested in our paper attempting to improve both the photocatalytic and photoelectrochemical activities under visible light irradiation.

Modification of $\mathrm{TiO}_{2}$ nanotubes $\left(\mathrm{TiO}_{2}-\mathrm{NT}\right)$ via incorporation of $\mathrm{g}-\mathrm{C}_{3} \mathrm{~N}_{4}$ and $\mathrm{Bi}_{2} \mathrm{O}_{3}$ is expected to improve the overall visible light activity when compared to naked $\mathrm{TiO}_{2}$. Compared to the VB edge of $\mathrm{TiO}_{2}(2.7 \mathrm{~V} v s$. NHE $(\mathrm{pH}=7)),{ }^{30}$ the band edge of $\mathrm{g}^{-} \mathrm{C}_{3} \mathrm{~N}_{4}$ is more negative $(1.4 \mathrm{~V}$ vs. NHE $(\mathrm{pH}=7)),{ }^{30}$ while the band edge of $\mathrm{Bi}_{2} \mathrm{O}_{3}$ is more positive $(3.13 \mathrm{~V} v$. $\mathrm{NHE}(\mathrm{pH}=7)){ }^{31}$ This combination should improve overall electron-hole separation and improve electron transfer characteristics.

In order to prepare the composite catalyst, we employed a thermal poly-condensation and dip-coating method to modify $\mathrm{TiO}_{2}$-NTs with g- $\mathrm{C}_{3} \mathrm{~N}_{4}$ and $\mathrm{Bi}_{2} \mathrm{O}_{3}$. The degradation of methylene blue (MB) and phenol by PEC performance was investigated using a composite catalyst as anode. The PEC performances of the composite electrodes were examined and the photocatalytic (PC) and electrocatalytic (EC) activities under identical reaction conditions were also compared. A mechanism to account for enhanced PEC activity was finally proposed.

\section{Experimental methods}

\subsection{Chemical reagents}

Oxalic acid dehydrate $\left((\mathrm{COOH})_{2} \cdot 2 \mathrm{H}_{2} \mathrm{O}\right)(\geq 99.5 \%$ purity), ammonium fluoride $\left(\mathrm{NH}_{4} \mathrm{~F}\right) \quad(\geq 96.0 \%$ purity $)$, melamine $\left(\mathrm{C}_{3} \mathrm{H}_{6} \mathrm{~N}_{6}\right) \quad(\geq 98.5 \%$ purity), bismuth nitrate pentahydrate $\left(\mathrm{Bi}\left(\mathrm{NO}_{3}\right)_{3} \cdot 5 \mathrm{H}_{2} \mathrm{O}\right)\left(\geq 99.0 \%\right.$ purity), methyl alcohol $\left(\mathrm{CH}_{3} \mathrm{OH}\right)$ ( $\geq 99.9 \%$ purity, HPLC, TEDIA company), ethylene glycol $\left(\mathrm{C}_{2} \mathrm{H}_{6} \mathrm{O}_{2}\right)\left(\geq 99.5 \%\right.$ purity), sodium sulfate $\left(\mathrm{Na}_{2} \mathrm{SO}_{4}\right)(\geq 99.0 \%$ purity), sodium sulfite $\left(\mathrm{Na}_{2} \mathrm{SO}_{3}\right)(\geq 97.0 \%$ purity) were all purchased from Hangzhou Huipu Chemical Reagent Co., Ltd.

\subsection{Synthesis of $\mathrm{g}-\mathrm{C}_{3} \mathrm{~N}_{4} / \mathrm{Bi}_{2} \mathrm{O}_{3} / \mathrm{TiO}_{2}$ nanotubes}

Electrochemical anodization method was used to prepare $\mathrm{TiO}_{2}$ NTs electrodes. The Ti sheet ( $0.5 \mathrm{~mm}$ thick, $99.5 \%$ purity) was washed by ultrasonic irradiation for $15 \mathrm{~min}$. The electrochemical reaction was operated using $\mathrm{Ti}$ sheet as anode and $\mathrm{Ni}$ sheet as cathode with the voltage of $20 \mathrm{~V}$ for $120 \mathrm{~min}$. The electrolyte was a mixed solution of $1 / 12 \mathrm{M}(\mathrm{COOH})_{2} \cdot 2 \mathrm{H}_{2} \mathrm{O}$ and $0.5 \mathrm{wt} \% \mathrm{NH}_{4} \mathrm{~F}^{32,33}$ Metal-free $\mathrm{g}-\mathrm{C}_{3} \mathrm{~N}_{4}$ powders were prepared by calcination of melamine to $520{ }^{\circ} \mathrm{C}$ for $4 \mathrm{~h}^{34}$

The $\mathrm{g}-\mathrm{C}_{3} \mathrm{~N}_{4} / \mathrm{Bi}_{2} \mathrm{O}_{3} / \mathrm{TiO}_{2}$-NTs composites were prepared by a dip-coating method in which $0.2 \mathrm{~g} g-\mathrm{C}_{3} \mathrm{~N}_{4}$ and $0.243 \mathrm{~g}$ $\mathrm{Bi}\left(\mathrm{NO}_{3}\right)_{3} \cdot 5 \mathrm{H}_{2} \mathrm{O}$ were dispersed in $20 \mathrm{~mL}$ of ethylene glycol solution; the $\mathrm{TiO}_{2}$-NTs that were still attached to the Ti sheet were slowly dipped up and down from the above solution for $30 \mathrm{~min}$. The dipped coated sheets were then annealed at $400{ }^{\circ} \mathrm{C}$ for $2 \mathrm{~h}^{33}$ When $\mathrm{g}-\mathrm{C}_{3} \mathrm{~N}_{4} / \mathrm{TiO}_{2}$-NTs or $\mathrm{Bi}_{2} \mathrm{O}_{3} / \mathrm{TiO}_{2}-\mathrm{NTs}$ were prepared, the precursor solution was changed to $0.2 \mathrm{~g}$ $\mathrm{g}-\mathrm{C}_{3} \mathrm{~N}_{4}$ or $0.243 \mathrm{~g} \mathrm{Bi}\left(\mathrm{NO}_{3}\right)_{3} \cdot 5 \mathrm{H}_{2} \mathrm{O}$ in $20 \mathrm{~mL}$ of ethylene glycol solution.

\subsection{Characterization of the synthesized g- $\mathrm{C}_{3} \mathrm{~N}_{4} / \mathrm{Bi}_{2} \mathrm{O}_{3} / \mathrm{TiO}_{2}$ nanotubes}

The synthesized materials $\left(\mathrm{TiO}_{2}-\mathrm{NTs}, \mathrm{g}-\mathrm{C}_{3} \mathrm{~N}_{4} / \mathrm{TiO}_{2}-\mathrm{NTs}, \mathrm{Bi}_{2} \mathrm{O}_{3} /\right.$ $\mathrm{TiO}_{2}$-NTs and $\mathrm{g}$ - $\mathrm{C}_{3} \mathrm{~N}_{4} / \mathrm{Bi}_{2} \mathrm{O}_{3} / \mathrm{TiO}_{2}$-NTs) were characterized by $\mathrm{X}$-ray diffractometer (XRD), X-ray photoelectron spectroscope (XPS), emission scanning electron microscope (FE-SEM, Hitachi S-4700 II) with an energy-dispersive X-ray spectrometer (EDX), transmission electron microscope (TEM) and UV-vis diffuse reflectance spectra (DRS).

\subsection{PEC experimental techniques}

The PEC properties of each sample were determined using an electrochemical workstation (CHI 660D). Modified $\mathrm{TiO}_{2}$-NTs electrodes were used as working electrodes with saturated Ag/ $\mathrm{AgCl}$ electrode as a reference electrode and Pt sheet as a counter electrode, respectively. Visible light at an intensity of $100 \mathrm{~mW} \mathrm{~cm}^{-2}$ was obtained by using a Xe-lamp light source with UV filter $(\lambda>420 \mathrm{~nm})$. Photocurrents and incident-photonto-current efficiencies (IPCE) were tested in mixed $0.1 \mathrm{M} \mathrm{Na}_{2} \mathrm{SO}_{4}$ and $\mathrm{Na}_{2} \mathrm{SO}_{3}$ solutions at $\mathrm{pH}$ of 10.5. IPCE measurements were taken at the visible wavelengths of 400, 430, 450, 475, 500, 550, 600 and $633 \mathrm{~nm}$ with a light intensity meter (model FZ-A). MottSchottky (M-S) plots and Nyquist plots were taken in $0.1 \mathrm{M}$ $\mathrm{Na}_{2} \mathrm{SO}_{4}$ solutions at $\mathrm{pH}=7.6$. $\mathrm{M}-\mathrm{S}$ plots were obtained at frequencies of 500, 1000 and $3000 \mathrm{~Hz}$ at an $\mathrm{AC}$ amplitude of 5 $\mathrm{mV}$. Nyquist plots were obtained both under dark and visible light conditions. The experiments including Nyquist plots, LSVs and IPCE plots were repeated for 3 times.

The activity of the prepared catalyst was assessed in three different modes of operation that include (1) photocatalytic (PC), (2) electrocatalytic (EC) and photoelectrocatalytic (PEC). The applied potential in EC and PEC process was 3.0 V. In each case, an electrolyte solution consisting of $0.1 \mathrm{M} \mathrm{Na}_{2} \mathrm{SO}_{4}$ was irradiated with visible light that had an average light intensity of $200 \mathrm{~mW} \mathrm{~cm}^{-2}$. $\mathrm{MB}\left(100 \mathrm{~mL}, 1 \times 10^{-5} \mathrm{M}\right.$, without regulating $\left.\mathrm{pH}\right)$ and phenol $\left(100 \mathrm{~mL}, 10 \mathrm{mg} \mathrm{L}^{-1}, \mathrm{pH}=3\right)$ fitted with an active electrode with a $4.5 \mathrm{~cm}^{2}$ effective surface area of $\mathrm{g}-\mathrm{C}_{3} \mathrm{~N}_{4} / \mathrm{Bi}_{2} \mathrm{O}_{3} /$ $\mathrm{TiO}_{2}$-NTs. Before initiating the reactions under illumination, the solution reacted with catalyst electrode for $30 \mathrm{~min}$ without light. At given time intervals, $3 \mathrm{~mL} \mathrm{MB}$ and $1 \mathrm{~mL}$ phenol aliquot samples were collected. The variation in the MB concentrations was recorded using an UV-vis spectrophotometer. The concentrations of phenol were analyzed by HPLC with a Diamonsil C18 column and ultraviolet detection at $278 \mathrm{~nm}$ with ratio of the deionized water and methanol of $6: 4(\mathrm{v} / \mathrm{v})$ and a flow rate of 1.0 $\mathrm{mL} \min ^{-1}$. The overall $\mathrm{MB}$ bleaching process and phenol degradation was fitted to pseudo first-order kinetics.

\section{Results and discussion}

\subsection{SEM and TEM analyses}

Fig. 1 shows the morphologies of $\mathrm{TiO}_{2}-\mathrm{NTs}, \mathrm{g}-\mathrm{C}_{3} \mathrm{~N}_{4} / \mathrm{TiO}_{2}-\mathrm{NTs}$, $\mathrm{Bi}_{2} \mathrm{O}_{3} / \mathrm{TiO}_{2}$-NTs, g- $\mathrm{C}_{3} \mathrm{~N}_{4} / \mathrm{Bi}_{2} \mathrm{O}_{3} / \mathrm{TiO}_{2}$-NTs, and pure g- $\mathrm{C}_{3} \mathrm{~N}_{4}$. The $\mathrm{TiO}_{2}$-NTs electrode has almost uniform holes and a highly ordered tubular structure. The average of the inner diameter of $\mathrm{TiO}_{2}$-NTs is close to $80 \mathrm{~nm}$, and their average of outer diameter 
is near $110 \mathrm{~nm}$. After modification, g- $\mathrm{C}_{3} \mathrm{~N}_{4} / \mathrm{TiO}_{2}-\mathrm{NTs}, \mathrm{Bi}_{2} \mathrm{O}_{3} /$ $\mathrm{TiO}_{2}$-NTs, g- $\mathrm{C}_{3} \mathrm{~N}_{4} / \mathrm{Bi}_{2} \mathrm{O}_{3} / \mathrm{TiO}_{2}$-NTs have very similar tubular structures. The $\mathrm{g}-\mathrm{C}_{3} \mathrm{~N}_{4}$ powders are likely sheet structures, as shown in Fig. 1(e), accumulating on the surface of $\mathrm{g}-\mathrm{C}_{3} \mathrm{~N}_{4} / \mathrm{TiO}_{2}$ NTs. The cross section of the $\mathrm{TiO}_{2}$ nanotubes was depicted in Fig. 1(f) showing that the mean length of the $\mathrm{TiO}_{2}$ nanotubes was about $850 \mathrm{~nm}$. Moreover, the EDX analysis (Fig. S1 in ESI $\dagger$ ) confirms that $\mathrm{Ti}, \mathrm{O}, \mathrm{C}, \mathrm{N}, \mathrm{Bi}$ exist in composite material and shows that $\mathrm{g}-\mathrm{C}_{3} \mathrm{~N}_{4}$ and $\mathrm{Bi}_{2} \mathrm{O}_{3}$ are deposited on $\mathrm{TiO}_{2}$ tubular substrates.

Fig. 2 shows the TEM analysis for $\mathrm{g}-\mathrm{C}_{3} \mathrm{~N}_{4} / \mathrm{Bi}_{2} \mathrm{O}_{3} / \mathrm{TiO}_{2}$ composite. The particles also detected in $\mathrm{g}-\mathrm{C}_{3} \mathrm{~N}_{4} / \mathrm{TiO}_{2}$ and $\mathrm{Bi}_{2} \mathrm{O}_{3} / \mathrm{TiO}_{2}$ composites, so $\mathrm{g}-\mathrm{C}_{3} \mathrm{~N}_{4}$ and $\mathrm{Bi}_{2} \mathrm{O}_{3}$ could be found in the nanotubes. And combined with SEM in Fig. 1, the $\mathrm{g}-\mathrm{C}_{3} \mathrm{~N}_{4}$ powders also accumulate on the surface of $\mathrm{g}-\mathrm{C}_{3} \mathrm{~N}_{4} / \mathrm{TiO}_{2}-\mathrm{NTs}$ and g- $\mathrm{C}_{3} \mathrm{~N}_{4} / \mathrm{Bi}_{2} \mathrm{O}_{3} / \mathrm{TiO}_{2}$-NTs composites, but little $\mathrm{Bi}_{2} \mathrm{O}_{3}$ was accumulated on the surface of $\mathrm{Bi}_{2} \mathrm{O}_{3} / \mathrm{TiO}_{2}$-NTs. It was probably due to that $\mathrm{Bi}_{2} \mathrm{O}_{3}$ was prepared by anneal of $\mathrm{Bi}\left(\mathrm{NO}_{3}\right)_{3} \cdot 5 \mathrm{H}_{2} \mathrm{O}$, which may permeate into the tube of $\mathrm{TiO}_{2}$ and $\mathrm{Bi}_{2} \mathrm{O}_{3}$ was formed. But g- $\mathrm{C}_{3} \mathrm{~N}_{4}$ was prepared at first and was like the sheet structures, so some small sheets were deposited into the tubes of $\mathrm{TiO}_{2}$ and some were accumulated on the surfaces of the tubes.

\subsection{XRD and XPS analyses}

The XRD analysis was applied to detect the formation of $\mathrm{TiO}_{2}$, g- $\mathrm{C}_{3} \mathrm{~N}_{4}$ and $\mathrm{Bi}_{2} \mathrm{O}_{3}$ in the composite electrode. However, due to the very low level of incorporated $\mathrm{Bi}_{2} \mathrm{O}_{3}$, the characteristic peak of $\mathrm{Bi}_{2} \mathrm{O}_{3}$ in $\mathrm{g}-\mathrm{C}_{3} \mathrm{~N}_{4} / \mathrm{Bi}_{2} \mathrm{O}_{3} / \mathrm{TiO}_{2}$-NTs was not seen. In another synthesis the amount of $\mathrm{Bi}\left(\mathrm{NO}_{3}\right)_{3} \cdot 5 \mathrm{H}_{2} \mathrm{O}$ was increased to
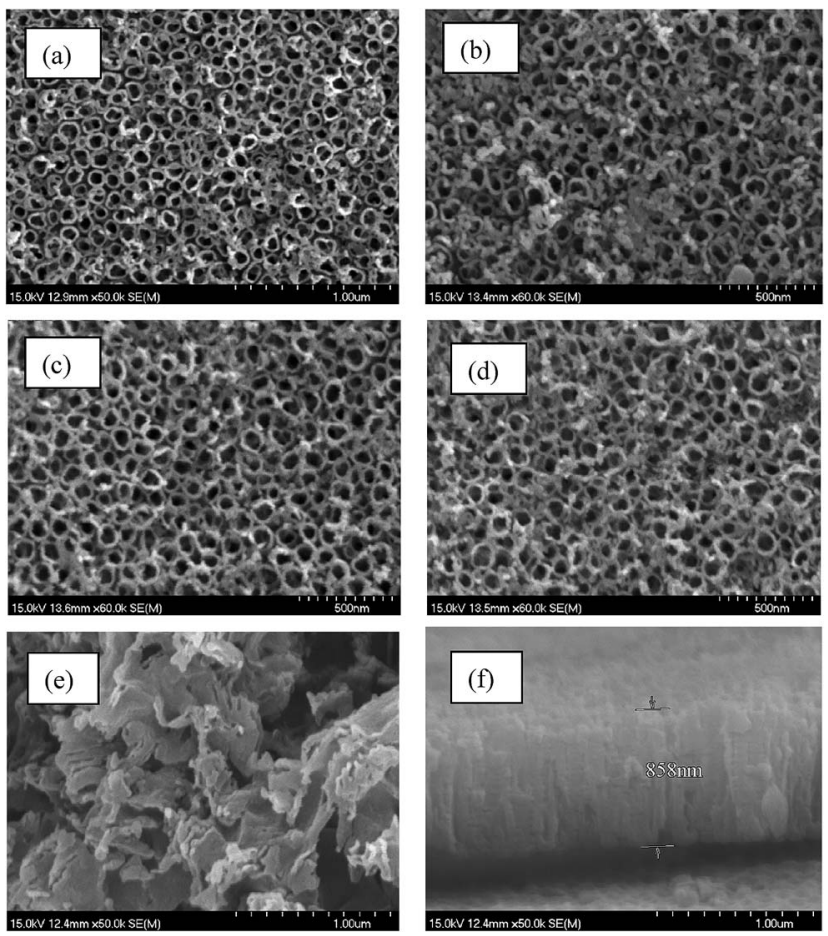

Fig. 1 SEM images of $\mathrm{TiO}_{2}-\mathrm{NTs}(\mathrm{a}), \mathrm{g}-\mathrm{C}_{3} \mathrm{~N}_{4} / \mathrm{TiO}_{2}-\mathrm{NTs}$ (b), $\mathrm{Bi}_{2} \mathrm{O}_{3} / \mathrm{TiO}_{2}-$ NTs (c), g- $\mathrm{C}_{3} \mathrm{~N}_{4} / \mathrm{Bi}_{2} \mathrm{O}_{3} / \mathrm{TiO}_{2}-\mathrm{NTs}$ (d), g- $\mathrm{C}_{3} \mathrm{~N}_{4}$ powders (e) and cross section of the $\mathrm{TiO}_{2}$ nanotubes (f).
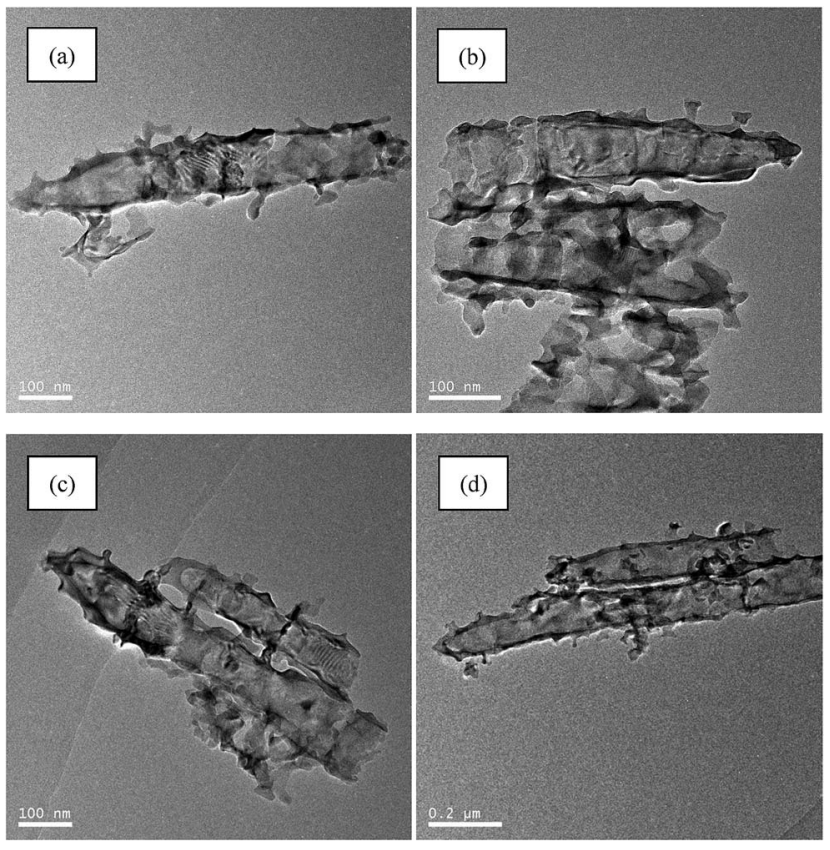

Fig. 2 TEM analysis for $\mathrm{g}-\mathrm{C}_{3} \mathrm{~N}_{4} / \mathrm{TiO}_{2}$ (a), $\mathrm{Bi}_{2} \mathrm{O}_{3} / \mathrm{TiO}_{2}$ (b) and different magnifications of $\mathrm{g}-\mathrm{C}_{3} \mathrm{~N}_{4} / \mathrm{Bi}_{2} \mathrm{O}_{3} / \mathrm{TiO}_{2}$ (c and d) composites.

$2.910 \mathrm{~g}$ in $20 \mathrm{~mL}$ of ethylene glycol, which was then dipped coated and annealed to get the fully loaded $\mathrm{g}-\mathrm{C}_{3} \mathrm{~N}_{4} / \mathrm{Bi}_{2} \mathrm{O}_{3} / \mathrm{TiO}_{2}$ NTs. Fig. 3 shows the XRD patterns for the $\mathrm{TiO}_{2}-\mathrm{NTs}$ and $\mathrm{g}-\mathrm{C}_{3} \mathrm{~N}_{4} /$ $\mathrm{Bi}_{2} \mathrm{O}_{3} / \mathrm{TiO}_{2}$-NTs electrodes that were annealed at $400{ }^{\circ} \mathrm{C}$. The peak of $2 \theta=25.2^{\circ}$ for anatase $\mathrm{TiO}_{2}$ can be seen in both of the XRD patterns. The characteristic peaks corresponding to g- $\mathrm{C}_{3} \mathrm{~N}_{4}, \mathrm{Bi}_{2} \mathrm{O}_{3}$ are also evident in Fig. 3, which confirms that g- $\mathrm{C}_{3} \mathrm{~N}_{4}, \mathrm{Bi}_{2} \mathrm{O}_{3}$ had been successfully synthesized.

In addition, the XPS analysis of $\mathrm{g}-\mathrm{C}_{3} \mathrm{~N}_{4} / \mathrm{Bi}_{2} \mathrm{O}_{3} / \mathrm{TiO}_{2}$-NTs electrode is also depicted in Fig. 4, which showed the existence of $\mathrm{Ti}$ $2 \mathrm{p}, \mathrm{O} 1 \mathrm{~s}, \mathrm{C} 1 \mathrm{~s}, \mathrm{~N}$ 1s and $\mathrm{Bi} 4 \mathrm{f}$ elements. In the inset figure of Fig. 3, two peaks centered at 164.3 and $158.9 \mathrm{eV}$ belong to $\mathrm{Bi} 4 \mathrm{f}_{5 / 2}$ and $\mathrm{Bi} 4 \mathrm{f}_{7 / 2}$ region, which should be determined as $\mathrm{Bi}_{2} \mathrm{O}_{3}$ species. ${ }^{35}$ While, near the main peaks due to $\mathrm{Bi}^{3+}$, there are other two small peaks centered at $157.2 \mathrm{eV}$ and $162.6 \mathrm{eV}$, which

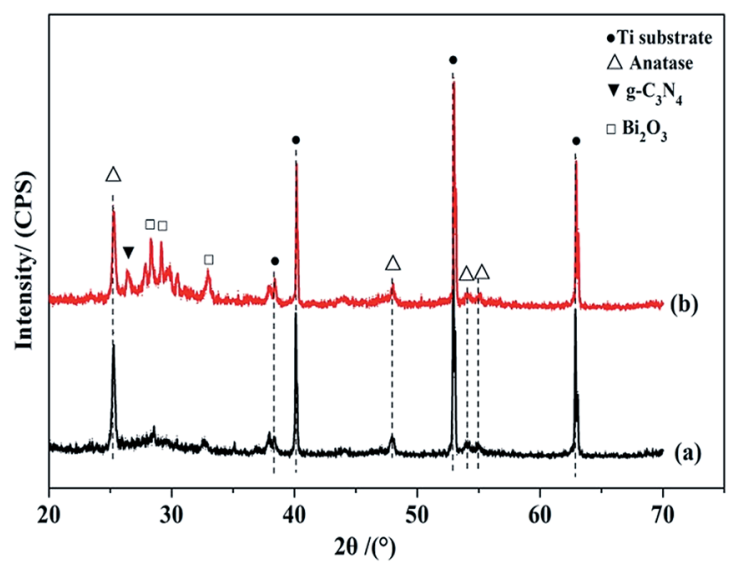

Fig. 3 XRD patterns of $\mathrm{TiO}_{2}-\mathrm{NTs}(\mathrm{a})$ and $\mathrm{g}-\mathrm{C}_{3} \mathrm{~N}_{4} / \mathrm{Bi}_{2} \mathrm{O}_{3} / \mathrm{TiO}_{2}-\mathrm{NTs}$ (b). 
probably belong to reduced $\mathrm{Bi}$ oxidation phase or $\mathrm{Bi}^{0} .^{36,37}$ Based on several studies about the reduced Bi phase, it could interact with the structure of $\mathrm{Bi}$ oxidation and titania to form the electronic effect between these two oxides. ${ }^{36,38}$

\subsection{UV-vis DRS analyses}

UV-vis DRS of the composite $\mathrm{TiO}_{2}$-NTs electrodes modified by g- $\mathrm{C}_{3} \mathrm{~N}_{4}$ and $\mathrm{Bi}_{2} \mathrm{O}_{3}$ are shown in Fig. 5. The spectrum of $\mathrm{g}-\mathrm{C}_{3} \mathrm{~N}_{4}$ / $\mathrm{TiO}_{2}$-NTs is similar to that of unmodified $\mathrm{TiO}_{2}$-NTs from 220 to $600 \mathrm{~nm}$. While from 220 to $370 \mathrm{~nm}$, the spectrum shows $\mathrm{Bi}_{2} \mathrm{O}_{3} /$ $\mathrm{TiO}_{2}$-NTs has a lower absorbance when compared to the unmodified $\mathrm{TiO}_{2}$-NTs, while $\mathrm{g}-\mathrm{C}_{3} \mathrm{~N}_{4} / \mathrm{Bi}_{2} \mathrm{O}_{3} / \mathrm{TiO}_{2}$-NTs showed an increase in absorbance compared to naked $\mathrm{TiO}_{2}$. When wavelength is larger than $370 \mathrm{~nm}$, however, the absorbance of $\mathrm{Bi}_{2} \mathrm{O}_{3} /$ $\mathrm{TiO}_{2}$-NTs, g- $\mathrm{C}_{3} \mathrm{~N}_{4} / \mathrm{Bi}_{2} \mathrm{O}_{3} / \mathrm{TiO}_{2}$-NTs are higher than that of the naked $\mathrm{TiO}_{2}$-NTs. In the case of $\mathrm{g}-\mathrm{C}_{3} \mathrm{~N}_{4} / \mathrm{Bi}_{2} \mathrm{O}_{3} / \mathrm{TiO}_{2}-\mathrm{NTs}$ electrode, the absorbance is significantly higher than for the other electrodes in UV-visible region. All of the samples have some degree of visible light absorbance $(\lambda>400 \mathrm{~nm})$, however this may be due, in part, to the roughness of the electrode surfaces with pores. ${ }^{39-41}$

From Fig. 5, the absorption edges of $\mathrm{TiO}_{2}-\mathrm{NTs}, \mathrm{g}-\mathrm{C}_{3} \mathrm{~N}_{4} / \mathrm{TiO}_{2}-$ NTs, $\mathrm{Bi}_{2} \mathrm{O}_{3} / \mathrm{TiO}_{2}$-NTs and $\mathrm{g}-\mathrm{C}_{3} \mathrm{~N}_{4} / \mathrm{Bi}_{2} \mathrm{O}_{3} / \mathrm{TiO}_{2}$-NTs are located approximately at $382 \mathrm{~nm}, 388 \mathrm{~nm}, 400 \mathrm{~nm}$, and $410 \mathrm{~nm}$, indicating that addition of $\mathrm{g}-\mathrm{C}_{3} \mathrm{~N}_{4}$ and $\mathrm{Bi}_{2} \mathrm{O}_{3}$ to the nanotube array extends the absorption to visible range. The corresponding band gap energies were determined using the standard equation as shown belong in eqn (1): ${ }^{42}$

$$
\alpha h \nu=A\left(h \nu-E_{\mathrm{g}}\right)^{n / 2}
$$

where $\alpha, h, \nu, E_{\mathrm{g}}$ and $A$ are the absorption coefficient, Planck's constant, light frequency, band gap energy, and a constant, respectively. For $\mathrm{TiO}_{2}, n$ is 4 for the indirect transition. ${ }^{24}$ Thus, plots of $(\alpha h \nu)^{1 / 2}$ versus photon energy $(h \nu)$ are obtained. As shown in Fig. S2, $\uparrow$ the $E_{\mathrm{g}}$ of $\mathrm{TiO}_{2}-\mathrm{NTs}$ is $3.25 \mathrm{eV}$, which is similar to anatase $\mathrm{TiO}_{2},{ }^{43}$ while the $E_{\mathrm{g}}$ values for $\mathrm{g}-\mathrm{C}_{3} \mathrm{~N}_{4} / \mathrm{TiO}_{2}-\mathrm{NTs}$, $\mathrm{Bi}_{2} \mathrm{O}_{3} / \mathrm{TiO}_{2}$-NTs and $\mathrm{g}-\mathrm{C}_{3} \mathrm{~N}_{4} / \mathrm{Bi}_{2} \mathrm{O}_{3} / \mathrm{TiO}_{2}$-NTs are $3.20 \mathrm{eV}, 3.10 \mathrm{eV}$ and $3.02 \mathrm{eV}$, respectively. The UV-vis DRS analysis was detected

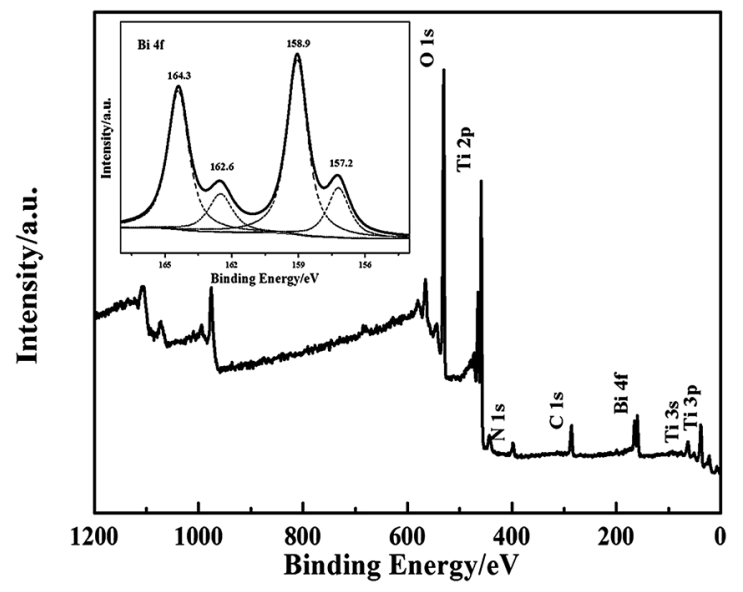

Fig. 4 XPS spectra of $\mathrm{g}-\mathrm{C}_{3} \mathrm{~N}_{4} / \mathrm{Bi}_{2} \mathrm{O}_{3} / \mathrm{TiO}_{2}-\mathrm{NTs}$.

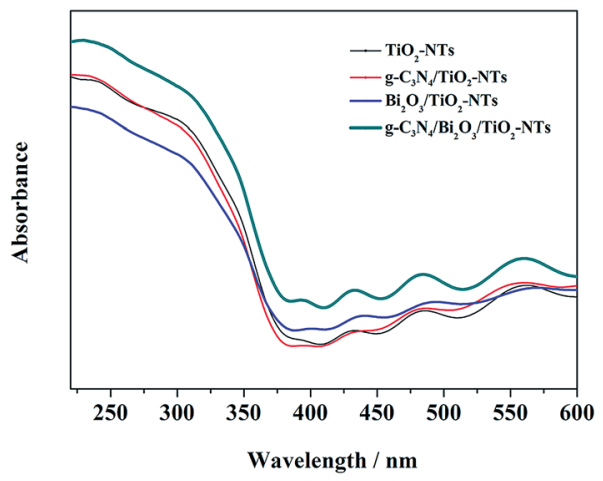

Fig. 5 UV-vis DRS of $\mathrm{TiO}_{2}-\mathrm{NTs}, \mathrm{g}-\mathrm{C}_{3} \mathrm{~N}_{4} / \mathrm{TiO}_{2}-\mathrm{NTs}, \mathrm{Bi}_{2} \mathrm{O}_{3} / \mathrm{TiO}_{2}-\mathrm{NTs}$ and $\mathrm{g}-\mathrm{C}_{3} \mathrm{~N}_{4} / \mathrm{Bi}_{2} \mathrm{O}_{3} / \mathrm{TiO}_{2}-\mathrm{NTs}$.

three times and the $E_{\mathrm{g}}$ was changed a little. It was probably that there was a small amount of $\mathrm{Bi}_{2} \mathrm{O}_{3}$ and $\mathrm{C}_{3} \mathrm{~N}_{4}$ were incorporated with $\mathrm{TiO}_{2}$ using a dip-coating method, which leads the red shift not significant. ${ }^{44,45}$

\subsection{Nyquist and $M-S$ plots}

In order to investigate the capacitance and resistance of the electrodes, Nyquist plots of the $\mathrm{TiO}_{2}$-NTs electrodes as modified by $\mathrm{g}-\mathrm{C}_{3} \mathrm{~N}_{4}$ and $\mathrm{Bi}_{2} \mathrm{O}_{3}$ are shown in Fig. 6. Only one arc was observed for each electrode while the arc radius of $\mathrm{g}-\mathrm{C}_{3} \mathrm{~N}_{4}$ / $\mathrm{Bi}_{2} \mathrm{O}_{3} / \mathrm{TiO}_{2}$-NTs was the smallest in dark and visible light irradiation. It implies that interfacial charge transfer is enhanced by a higher efficiency of charge separation.

The $\mathrm{M}-\mathrm{S}$ plots, as shown in Fig. 7, reveal the flat band potential $\left(E_{\mathrm{fb}}\right)$ and interfacial charge transfer of the electrode, in which $C_{\mathrm{sc}}{ }^{2}$ means the space charge capacitance of the electrode. ${ }^{46,47}$ The $E_{\mathrm{fb}}$ shifts positively from $c a .-0.75 \mathrm{~V}$ for $\mathrm{TiO}_{2}$-NTs to $-0.40 \mathrm{~V}$ for $\mathrm{g}-\mathrm{C}_{3} \mathrm{~N}_{4} / \mathrm{Bi}_{2} \mathrm{O}_{3} / \mathrm{TiO}_{2}$-NTs. Similarly, the onset potential of anodic photocurrent shifts positively from $\mathrm{ca}$. -0.54 $\mathrm{V}$ for $\mathrm{TiO}_{2}$-NTs to $-0.35 \mathrm{~V}$ for $\mathrm{g}-\mathrm{C}_{3} \mathrm{~N}_{4} / \mathrm{Bi}_{2} \mathrm{O}_{3} / \mathrm{TiO}_{2}-\mathrm{NTs}$ as shown in Fig. S3. $\dagger$ In both of samples, photocurrent onset potentials are more positive than the $E_{\mathrm{fb}}$. It is probably due to the recombination of electron-hole more quickly for water oxidation, so more positive potentials are achieved for transmission of charge. ${ }^{48}$

The g- $\mathrm{C}_{3} \mathrm{~N}_{4} / \mathrm{Bi}_{2} \mathrm{O}_{3} / \mathrm{TiO}_{2}$-NTs electrode has the highest absorbance and narrowest $E_{\mathrm{g}}$, as shown in Fig. 5. Combined with $E_{\mathrm{fb}}$ and $E_{\mathrm{g}},{ }^{32}$ the VB edge of $\mathrm{TiO}_{2}-\mathrm{NTs}$ and $\mathrm{g}-\mathrm{C}_{3} \mathrm{~N}_{4} / \mathrm{Bi}_{2} \mathrm{O}_{3} / \mathrm{TiO}_{2}$-NTs electrode is calculated at $2.50 \mathrm{~V}$ and $2.62 \mathrm{~V}$, respectively. As a result, the improvement of water oxidation ability of $\mathrm{g}-\mathrm{C}_{3} \mathrm{~N}_{4}$ / $\mathrm{Bi}_{2} \mathrm{O}_{3} / \mathrm{TiO}_{2}$-NTs was achieved for the enhancing of PEC properties. $^{49}$

\subsection{PEC properties}

Linear sweep voltammetry (LSV) method was used to analyze the PEC activities of the composite $\mathrm{TiO}_{2}$-NTs electrodes. In comparison, LSVs without irradiation were also tested, which shows the surface catalytic property of electrodes for $\mathrm{O}_{2}$ evolution. ${ }^{50}$ From Fig. 8, most of the composite $\mathrm{TiO}_{2}$-NTs electrodes show a current response until the bias potential is at least $1.0 \mathrm{~V}$ 

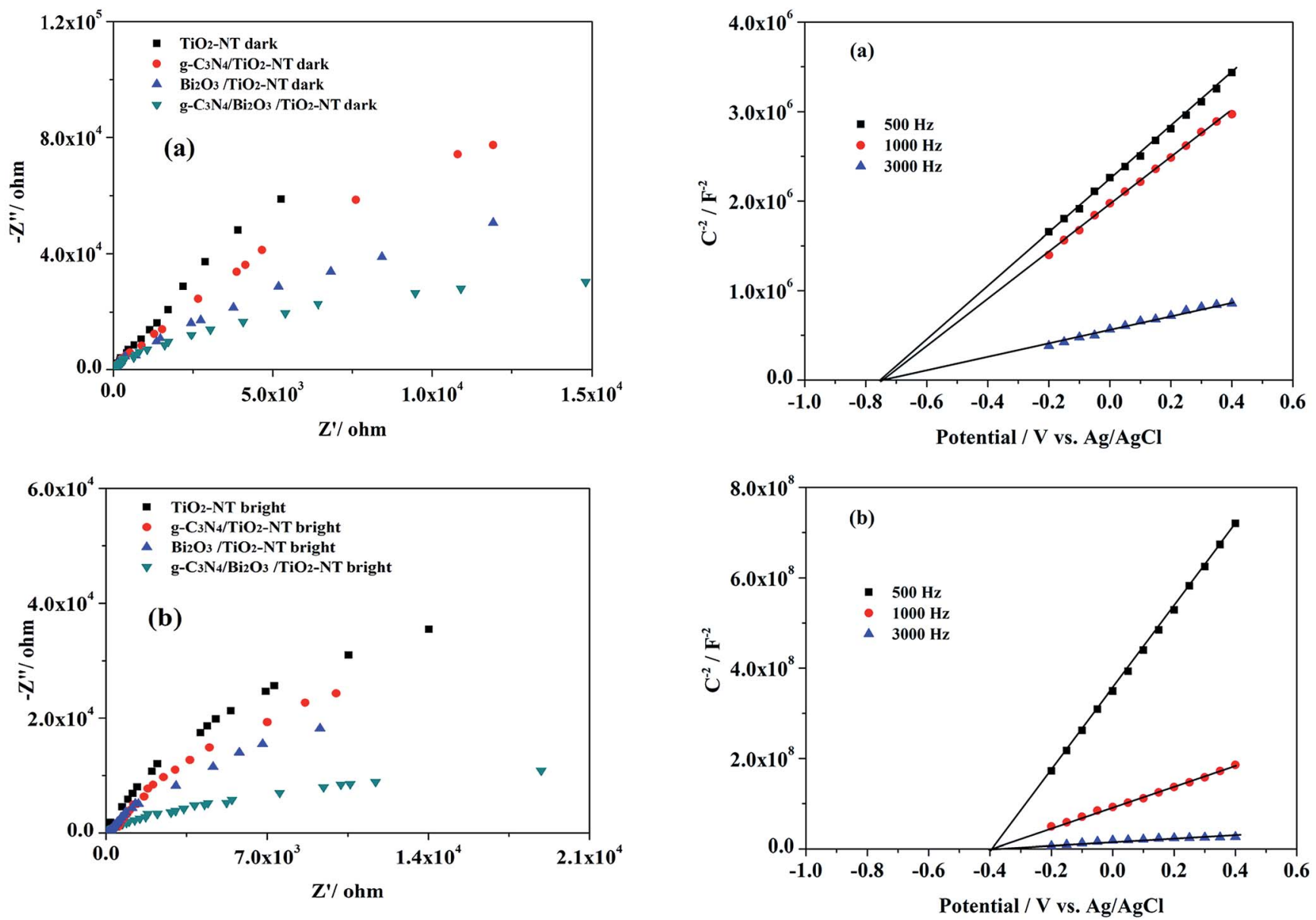

Fig. 6 Nyquist plots of $\mathrm{TiO}_{2}-\mathrm{NTs}, \mathrm{g}-\mathrm{C}_{3} \mathrm{~N}_{4} / \mathrm{TiO}_{2}-\mathrm{NTs}, \mathrm{Bi}_{2} \mathrm{O}_{3} / \mathrm{TiO}_{2}-\mathrm{NTs}$ and $\mathrm{g}-\mathrm{C}_{3} \mathrm{~N}_{4} / \mathrm{Bi}_{2} \mathrm{O}_{3} / \mathrm{TiO}_{2}-\mathrm{NT} \sin 0.1 \mathrm{M} \mathrm{Na}_{2} \mathrm{SO}_{4}$ aqueous solution $(\mathrm{pH}$ 7.6) in dark (a) and visible light (b) conditions with a frequency range of $10^{-2}$ to $10^{5} \mathrm{~Hz}$ and a scan rate of $5 \mathrm{mV} \mathrm{s}^{-1}$. Light intensity: 100 $\mathrm{mW} \mathrm{cm}{ }^{-2}$.

without irradiation. The $\mathrm{g}-\mathrm{C}_{3} \mathrm{~N}_{4} / \mathrm{Bi}_{2} \mathrm{O}_{3} / \mathrm{TiO}_{2}-\mathrm{NTs}$ electrode shows a positive shift of the onset potential (Fig. $\mathrm{S} 3 \dagger$ ) implying that the surface became easier for $\mathrm{O}_{2}$ evolution than the unmodified $\mathrm{TiO}_{2}$-NTs electrodes surface. Moreover, it indicates that the composite electrodes reduced the charge transfer resistance, ${ }^{50}$ which is consistent with result of EIS Nyquist analysis in Fig. 6.

Fig. 9 shows LSVs of the composite $\mathrm{TiO}_{2}$-NTs electrodes under visible light irradiation in $0.1 \mathrm{M} \mathrm{Na}_{2} \mathrm{SO}_{4}$ and $\mathrm{Na}_{2} \mathrm{SO}_{3}$ mixture solution. The photocurrent of g- $\mathrm{C}_{3} \mathrm{~N}_{4} / \mathrm{Bi}_{2} \mathrm{O}_{3} / \mathrm{TiO}_{2}-\mathrm{NTs}$ electrode is ca. 15 times larger than that of $\mathrm{TiO}_{2}$-NTs. $\mathrm{Bi}_{2} \mathrm{O}_{3} /$ $\mathrm{TiO}_{2}$-NTs electrode has a lightly lower photocurrent compared to $\mathrm{g}-\mathrm{C}_{3} \mathrm{~N}_{4} / \mathrm{Bi}_{2} \mathrm{O}_{3} / \mathrm{TiO}_{2}$-NTs, but its photocurrent is still over 8 times larger than that of $\mathrm{TiO}_{2}$-NTs. The recombination of photogenerated electron-hole decrease with the bias potential increase, and the driving force for photo-generated electrons transferring to the external circuit enhanced. The enhancement of photo-response of $\mathrm{g}-\mathrm{C}_{3} \mathrm{~N}_{4} / \mathrm{Bi}_{2} \mathrm{O}_{3} / \mathrm{TiO}_{2}$-NTs electrode under visible light irradiation is probably due to: (1) the higher absorbance and the wider absorption edge; (2) the improved driving force for $\mathrm{O}_{2}$ production; (3) the improved separation of photo-generated electron-hole pairs.

Fig. $7 \mathrm{M}$-S plots of the $\mathrm{TiO}_{2}-\mathrm{NTs}(\mathrm{a})$ and $\mathrm{g}-\mathrm{C}_{3} \mathrm{~N}_{4} / \mathrm{Bi}_{2} \mathrm{O}_{3} / \mathrm{TiO}_{2}-\mathrm{NTs}(\mathrm{b})$ electrodes in $0.1 \mathrm{M} \mathrm{Na}_{2} \mathrm{SO}_{4}$ aqueous solution ( $\mathrm{pH}$ 7.6) under dark condition with an $\mathrm{AC}$ amplitude of $5 \mathrm{mV}$ at each potential.

\subsection{IPCE}

Fig. 10 shows the IPCE plots as function of wavelength for the composite $\mathrm{TiO}_{2}$-NTs electrodes calculated by eqn (2): ${ }^{51,52}$

$$
\operatorname{IPCE}(\%)=1240 \times\left(i_{\mathrm{ph}} / \lambda P_{\text {in }}\right) \times 100
$$

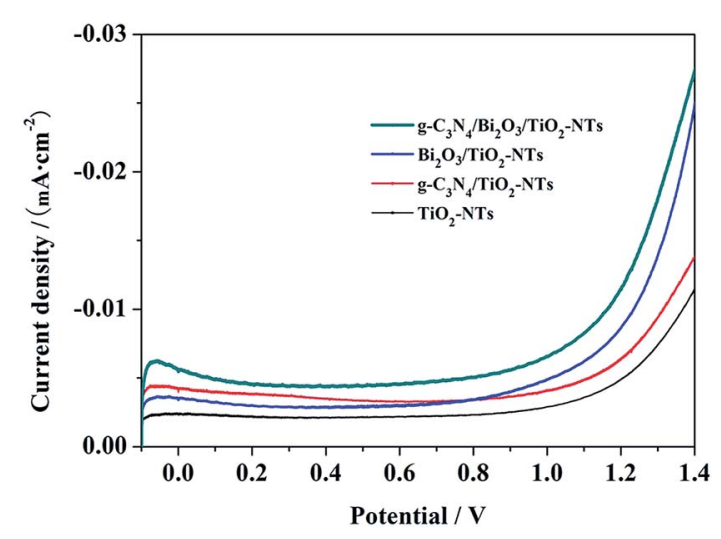

Fig. $8 \mathrm{LSVs}$ of $\mathrm{TiO}_{2}-\mathrm{NTs}, \mathrm{g}-\mathrm{C}_{3} \mathrm{~N}_{4} / \mathrm{TiO}_{2}-\mathrm{NTs}, \mathrm{Bi}_{2} \mathrm{O}_{3} / \mathrm{TiO}_{2}-\mathrm{NTs}$ and g- $\mathrm{C}_{3} \mathrm{~N}_{4} / \mathrm{Bi}_{2} \mathrm{O}_{3} / \mathrm{TiO}_{2}-\mathrm{NTs}$ in $0.1 \mathrm{M} \mathrm{Na}_{2} \mathrm{SO}_{4}$ and $\mathrm{Na}_{2} \mathrm{SO}_{3}$ mixed aqueous solution ( $\mathrm{pH}$ 10.5) under dark condition. Scan rate: $10 \mathrm{mV} \mathrm{s}^{-1}$. 


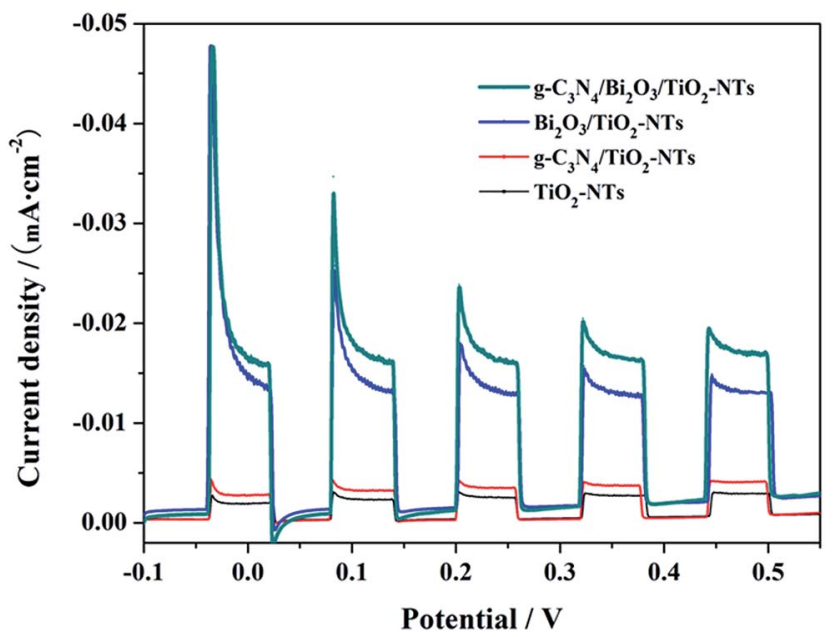

Fig. 9 LSVs of $\mathrm{TiO}_{2}-\mathrm{NTs}, \mathrm{g}-\mathrm{C}_{3} \mathrm{~N}_{4} / \mathrm{TiO}_{2}-\mathrm{NTs}, \mathrm{Bi}_{2} \mathrm{O}_{3} / \mathrm{TiO}_{2}-\mathrm{NTs}$ and g- $\mathrm{C}_{3} \mathrm{~N}_{4} / \mathrm{Bi}_{2} \mathrm{O}_{3} / \mathrm{TiO}_{2}-\mathrm{NTs}$ in $0.1 \mathrm{M} \mathrm{Na}_{2} \mathrm{SO}_{4}$ and $\mathrm{Na}_{2} \mathrm{SO}_{3}$ mixed aqueous solution $(\mathrm{pH}$ 10.5) under chopped visible light $(\lambda>420 \mathrm{~nm})$ irradiation. Scan rate: $10 \mathrm{mV} \mathrm{s}^{-1}$. Light intensity: $100 \mathrm{~mW} \mathrm{~cm}^{-2}$.

where $i_{\mathrm{ph}}$ is the photocurrent at $0.40 \mathrm{~V}(\mathrm{~mA}), \lambda$ is the wavelength $(\mathrm{nm})$ of light, and $P_{\text {in }}$ is the light power intensity at $\lambda(\mathrm{mW})$. The IPCE values decreased with increasing wavelength from 400 to $633 \mathrm{~nm}$. The g- $\mathrm{C}_{3} \mathrm{~N}_{4} / \mathrm{Bi}_{2} \mathrm{O}_{3} / \mathrm{TiO}_{2}-\mathrm{NTs}$ electrodes show the highest IPCE at $7.59 \%$ at $400 \mathrm{~nm}$, which amounts to an enhancement of $c a .55 \%$ when compared to the unmodified $\mathrm{TiO}_{2}$-NTs $(4.9 \%)$.

Zhou's and co-workers ${ }^{22}$ have developed boron and phosphor co-doped $\mathrm{TiO}_{2}$ nanotube arrays (BP-TNTs) by an anodization process on a $\mathrm{Ti}$ sheet, achieving the highest IPCE value $3.8 \%$ at $400 \mathrm{~nm}$. The same team also prepared a CN/TNT composite heterojunction photocatalyst, which had a maximum IPCE of $7.3 \%$ at $400 \mathrm{~nm} .{ }^{26} \mathrm{Jia}$ et $a l .{ }^{53}$ have synthesized polypyrrole (PPy) onto self-organized $\mathrm{TiO}_{2}$ nanotube arrays $\left(\mathrm{TiO}_{2}-\mathrm{NTs}\right)$, and the $\mathrm{PPy} / \mathrm{TiO}_{2}$-NTs electrode showed the

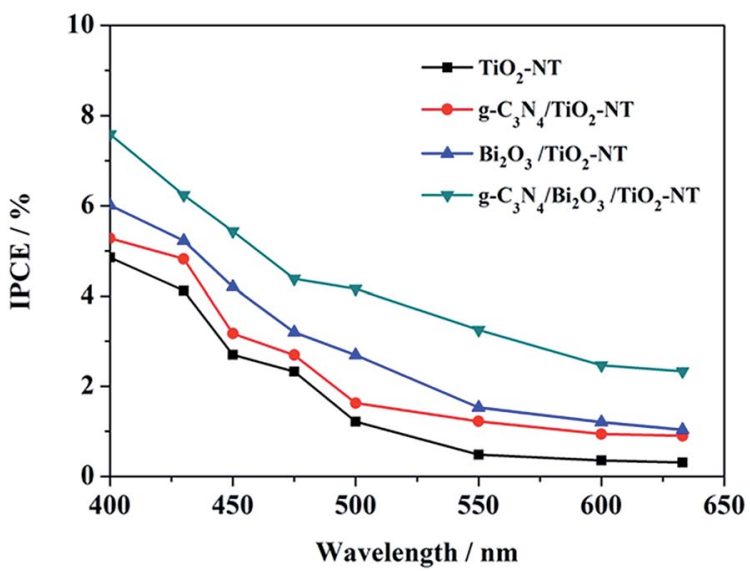

Fig. 10 IPCE plots of $\mathrm{TiO}_{2}-\mathrm{NTs}, \mathrm{g}-\mathrm{C}_{3} \mathrm{~N}_{4} / \mathrm{TiO}_{2}-\mathrm{NTs}, \mathrm{Bi}_{2} \mathrm{O}_{3} / \mathrm{TiO}_{2}-\mathrm{NTs}$ and $\mathrm{g}-\mathrm{C}_{3} \mathrm{~N}_{4} / \mathrm{Bi}_{2} \mathrm{O}_{3} / \mathrm{TiO}_{2}-\mathrm{NTs}$ calculated from the photocurrent in 0.1 $\mathrm{M} \mathrm{Na}_{2} \mathrm{SO}_{4}$ and $\mathrm{Na}_{2} \mathrm{SO}_{3}$ mixed aqueous solution ( $\mathrm{pH}$ 10.5) at an applied potential of $0.40 \mathrm{~V} v$ s. $\mathrm{Ag} / \mathrm{AgCl}$. Light intensity: $100 \mathrm{~mW} \mathrm{~cm}^{-2}$. maximum IPCE of $5 \%$ at $410 \mathrm{~nm}$. In contrast, the $\mathrm{g}-\mathrm{C}_{3} \mathrm{~N}_{4} / \mathrm{Bi}_{2} \mathrm{O}_{3} /$ $\mathrm{TiO}_{2}$-NTs electrode has higher IPCE in the visible.

\subsection{Pollutants degradation}

$\mathrm{MB}$ and phenol are degraded on the $\mathrm{g}-\mathrm{C}_{3} \mathrm{~N}_{4} / \mathrm{Bi}_{2} \mathrm{O}_{3} / \mathrm{TiO}_{2}$-NTs electrode in photolysis, EC, PC and PEC processes, respectively. Fig. 11 shows the removal efficiency of MB at 6.4\%, 8.8\%, 50.2\% and $77.9 \%$ after $3 \mathrm{~h}$ of reaction in photolysis, EC, PC and PEC process. The corresponding apparent rate constants $k=0.029$, 0.24 and $0.50 \mathrm{~h}^{-1}$ in EC, PC and PEC processes, respectively. The value of $k$ for MB degradation in PEC process is roughly 1.9 times as high as that in (EC + PC) process, indicating that synergistic effect occurred during PEC process. Fig. $\mathrm{S} 4 \dagger$ shows the absorbance spectra of $\mathrm{MB}$ degradation at $\mathrm{g}-\mathrm{C}_{3} \mathrm{~N}_{4} / \mathrm{Bi}_{2} \mathrm{O}_{3} /$ $\mathrm{TiO}_{2}$-NTs electrode in PEC process. There are three absorption peaks at 292, 246 and $665 \mathrm{~nm}$, in which peak at $665 \mathrm{~nm}$ belongs to the auxochrome group of $\mathrm{MB}$ and the peaks at $292 \mathrm{~nm}$ and $246 \mathrm{~nm}$ belong to the substituted benzenes ring structures. ${ }^{\mathbf{5 4 , 5 5}}$ It can be see that all of the peaks decreased during the reaction, which implied that the MB was bleached and the benzenes ring structures were also decomposed. In addition, before $235 \mathrm{~nm}$, the absorbance spectra of MB increased with time increasing, which possibly shows that some substituted benzene derivatives or other intermediate products may be formed. The analysis of the intermediates needs further investigation.

In addition, the colorless organic phenol also was degraded efficiently in PEC process by using g- $\mathrm{C}_{3} \mathrm{~N}_{4} / \mathrm{Bi}_{2} \mathrm{O}_{3} / \mathrm{TiO}_{2}$-NTs electrode as shown in Fig. S5. $\dagger$ Fig. S6† shows HPLC of phenol degradation at the $\mathrm{g}-\mathrm{C}_{3} \mathrm{~N}_{4} / \mathrm{Bi}_{2} \mathrm{O}_{3} / \mathrm{TiO}_{2}$-NTs electrode in PEC process. Compared with the standard compounds, hydroquinone and benzoquinone were produced after degradation as depicted in Fig. S6. $\dagger$ It probably indicated that phenol was degraded to form hydroquinone and then transformed to benzoquinone, and then the benzene rings were opened to form small molecular acids and finally could be mineralized.

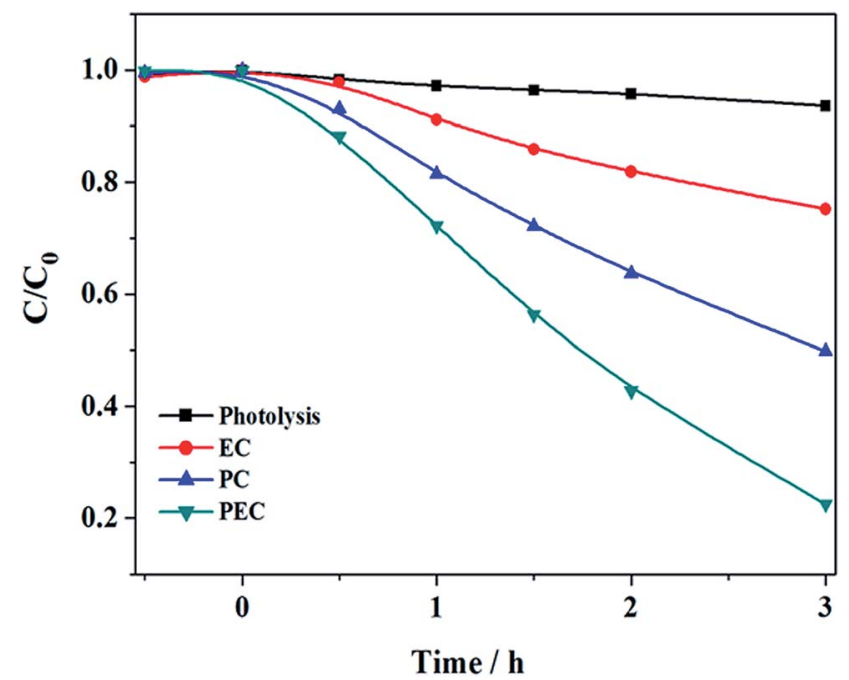

Fig. 11 Variation of [MB] concentration vs. time at the $g-\mathrm{C}_{3} \mathrm{~N}_{4} / \mathrm{Bi}_{2} \mathrm{O}_{3} /$ $\mathrm{TiO}_{2}$-NTs electrode in EC, $\mathrm{PC}$ and PEC processes. Applied potential: 3.0 V. Electrolyte: $0.1 \mathrm{M} \mathrm{Na}_{2} \mathrm{SO}_{4}, \mathrm{pH}=7.6$. 
Fig. 12 shows the concentration change of MB with different modified $\mathrm{TiO}_{2}$-NTs electrodes in PEC process. Correspondingly, the removal efficiency of $\mathrm{MB}$ is $37.3 \%, 41.1 \%, 55.3 \%$ and $77.5 \%$ for $\mathrm{TiO}_{2}$-NTs, g- $\mathrm{C}_{3} \mathrm{~N}_{4} / \mathrm{TiO}_{2}$-NTs, $\mathrm{Bi}_{2} \mathrm{O}_{3} / \mathrm{TiO}_{2}$-NTs, and g- $\mathrm{C}_{3} \mathrm{~N}_{4} /$ $\mathrm{Bi}_{2} \mathrm{O}_{3} / \mathrm{TiO}_{2}$-NTs after $3 \mathrm{~h}$ of reaction. Hence, the $\mathrm{g}-\mathrm{C}_{3} \mathrm{~N}_{4} / \mathrm{Bi}_{2} \mathrm{O}_{3} /$ $\mathrm{TiO}_{2}$-NTs electrode could contribute to the promotion of the PEC performance compared with $\mathrm{TiO}_{2}$-NTs electrode.

To check the stability of $\mathrm{g}-\mathrm{C}_{3} \mathrm{~N}_{4} / \mathrm{Bi}_{2} \mathrm{O}_{3} / \mathrm{TiO}_{2}$-NTs electrode, $\mathrm{MB}$ degradation using the PEC process was repeated for four times. As shown in Fig. 13, the degradation reaction is repeatable through four PEC reaction cycles. This indicates that $\mathrm{g}$ $\mathrm{C}_{3} \mathrm{~N}_{4} / \mathrm{Bi}_{2} \mathrm{O}_{3} / \mathrm{TiO}_{2}$-NTs electrode is reasonably stable during PEC processing.

\subsection{Possible considerations}

Based on the above results, suggested mechanism for charge separation and electron transfer in $\mathrm{g}-\mathrm{C}_{3} \mathrm{~N}_{4} / \mathrm{Bi}_{2} \mathrm{O}_{3} / \mathrm{TiO}_{2}-\mathrm{NTs}$ electrode is depicted schematically in Fig. 14. The bottoms of the conduction band (CB) of $\mathrm{TiO}_{2}, \mathrm{Bi}_{2} \mathrm{O}_{3}$ and $\mathrm{g}-\mathrm{C}_{3} \mathrm{~N}_{4}$ are located at about $-0.5 \mathrm{~V},+0.33 \mathrm{~V},-1.3 \mathrm{~V}$ vs. NHE $(\mathrm{pH}=7)$, respectively. ${ }^{30,31}$ The $E_{\mathrm{g}}$ of $\mathrm{Bi}_{2} \mathrm{O}_{3}(2.8 \mathrm{eV})$ and $\mathrm{g}-\mathrm{C}_{3} \mathrm{~N}_{4}(2.7 \mathrm{eV})$ are smaller than that for $\mathrm{TiO}_{2}(3.2 \mathrm{eV})$. Thus, only $\mathrm{Bi}_{2} \mathrm{O}_{3}$ and $\mathrm{g}-\mathrm{C}_{3} \mathrm{~N}_{4}$ can absorb photons and excite photoelectrons under visible light irradiation. One of possible mechanisms is that $\mathrm{TiO}_{2}$ is placed between $\mathrm{Bi}_{2} \mathrm{O}_{3}$ and $\mathrm{C}_{3} \mathrm{~N}_{4}$, which has advantage to electron-holes transfer. As shown in Fig. 14(a), with the accumulation of valence holes of $\mathrm{Bi}_{2} \mathrm{O}_{3}$, the photo-induced holes of $\mathrm{Bi}_{2} \mathrm{O}_{3}$ flow into the VB of the $\mathrm{TiO}_{2}$ layer and then into the VB of the $g-\mathrm{C}_{3} \mathrm{~N}_{4}$. Holes on the $\mathrm{g}-\mathrm{C}_{3} \mathrm{~N}_{4}$ surface can also degrade $\mathrm{MB}$, giving rise to enhance photocatalytic activity. ${ }^{56,57}$ Meanwhile, the electron injection is transferred from the $\mathrm{CB}$ of $\mathrm{g}-\mathrm{C}_{3} \mathrm{~N}_{4}$ into that of $\mathrm{TiO}_{2}$ and subsequently could be shuttled freely along g- $\mathrm{C}_{3} \mathrm{~N}_{4} / \mathrm{Bi}_{2} \mathrm{O}_{3} /$ $\mathrm{TiO}_{2}$-NTs matrix of the electrodes to the external circuit, enhancing the separation of electron-hole pairs. Moreover, photo-generated electrons of $\mathrm{Bi}_{2} \mathrm{O}_{3}$ can react with oxygen molecules to generate superoxide $\mathrm{O}_{2}{ }^{\cdot-}$, which leads to $\mathrm{H}_{2} \mathrm{O}_{2}$

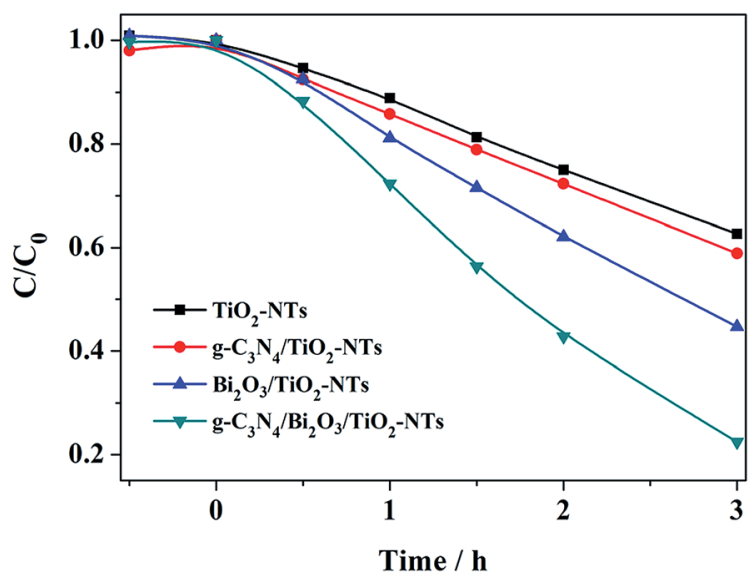

Fig. 12 The variation of $[\mathrm{MB}]$ vs. time at the $\mathrm{TiO}_{2}-\mathrm{NTs}, \mathrm{g}-\mathrm{C}_{3} \mathrm{~N}_{4} / \mathrm{TiO}_{2}-$ NTs, $\mathrm{Bi}_{2} \mathrm{O}_{3} / \mathrm{TiO}_{2}$-NTs, $\mathrm{g}-\mathrm{C}_{3} \mathrm{~N}_{4} / \mathrm{Bi}_{2} \mathrm{O}_{3} / \mathrm{TiO}_{2}-\mathrm{NTs}$ electrodes in PEC process with visible light irradiation. Applied potential: $3.0 \mathrm{~V}$. Electrolyte: $0.1 \mathrm{M} \mathrm{Na}_{2} \mathrm{SO}_{4}, \mathrm{pH}=7.6$.

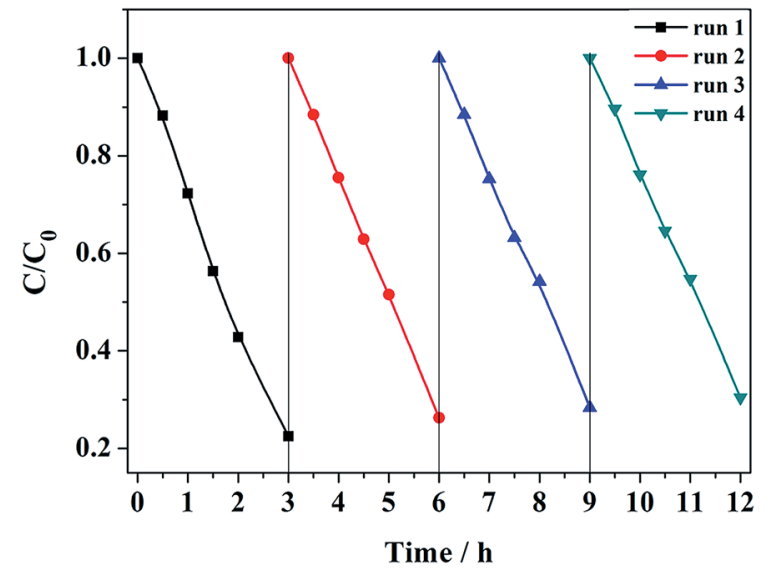

Fig. 13 Stability of the $\mathrm{g}-\mathrm{C}_{3} \mathrm{~N}_{4} / \mathrm{Bi}_{2} \mathrm{O}_{3} / \mathrm{TiO}_{2}-\mathrm{NTs}$ electrode for PEC degradation of $\mathrm{MB}$ experiments with visible light irradiation at an applied potential of 3.0 V. Electrolyte: $0.1 \mathrm{M} \mathrm{Na}_{2} \mathrm{SO}_{4}, \mathrm{pH}=7.6$.

production and eventual bleaching of MB. Even though the $\mathrm{TiO}_{2}$ interlayer isn't induced by visible light, it is used as a support and connector between $\mathrm{Bi}_{2} \mathrm{O}_{3}$ layers and $\mathrm{g}-\mathrm{C}_{3} \mathrm{~N}_{4}$ particles to improve the separation of electron-hole pairs. Key steps of the sequence of PEC reactions can be summarized as follows:

(a)
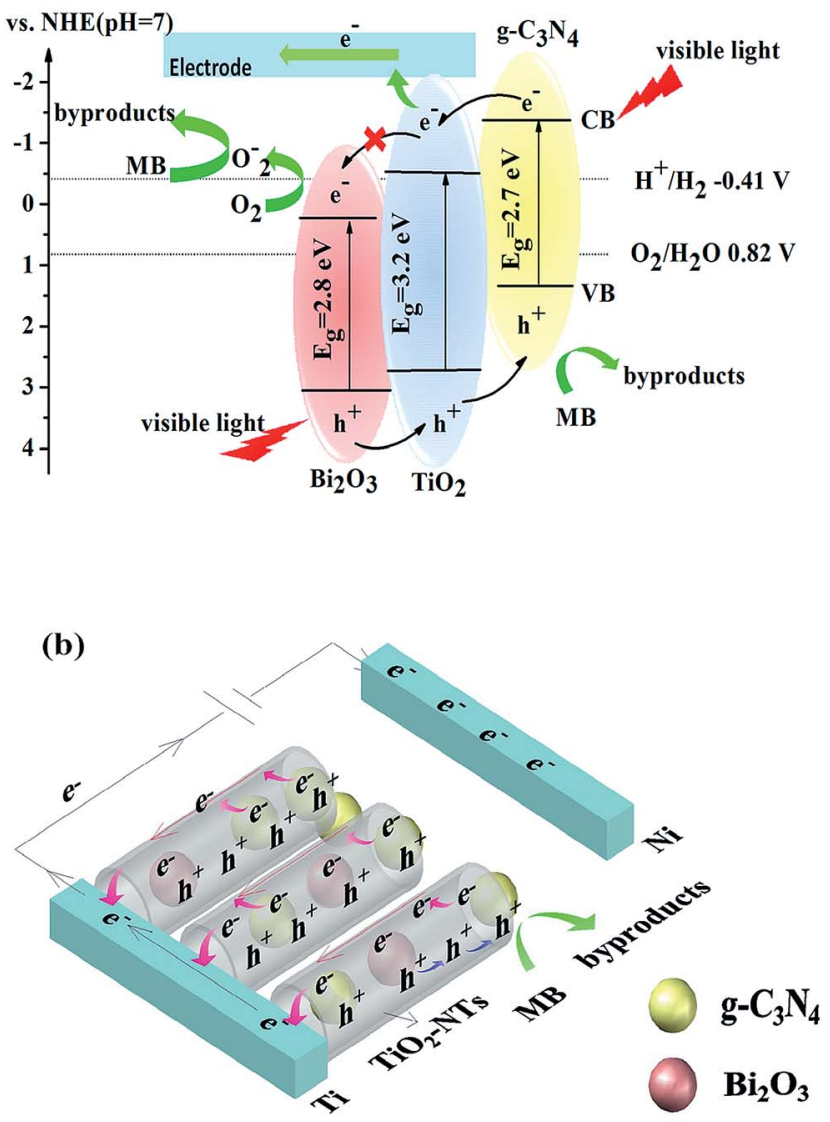

Fig. 14 One of suggested mechanism of charge separation and electron transfer in $\mathrm{g}-\mathrm{C}_{3} \mathrm{~N}_{4} / \mathrm{Bi}_{2} \mathrm{O}_{3} / \mathrm{TiO}_{2}$-NTs electrodes under visible light irradiation. 


$$
\begin{gathered}
\mathrm{Bi}_{2} \mathrm{O}_{3}+h \nu \rightarrow \mathrm{Bi}_{2} \mathrm{O}_{3}\left(\mathrm{~h}^{+}+\mathrm{e}^{-}\right) \\
\mathrm{g}-\mathrm{C}_{3} \mathrm{~N}_{4}+h \nu \rightarrow \mathrm{g}-\mathrm{C}_{3} \mathrm{~N}_{4}\left(\mathrm{~h}^{+}+\mathrm{e}^{-}\right) \\
\mathrm{Bi}_{2} \mathrm{O}_{3}\left(\mathrm{~h}^{+}\right)+\mathrm{TiO}_{2} \rightarrow \mathrm{TiO}_{2}\left(\mathrm{~h}^{+}\right)+\mathrm{Bi}_{2} \mathrm{O}_{3} \\
\mathrm{TiO}_{2}\left(\mathrm{~h}^{+}\right)+\mathrm{g}_{-} \mathrm{C}_{3} \mathrm{~N}_{4} \rightarrow \mathrm{g}_{-} \mathrm{C}_{3} \mathrm{~N}_{4}\left(\mathrm{~h}^{+}\right)+\mathrm{TiO}_{2} \\
\mathrm{~g}_{-} \mathrm{C}_{3} \mathrm{~N}_{4}\left(\mathrm{e}^{-}\right)+\mathrm{TiO}_{2} \rightarrow \mathrm{TiO}_{2}\left(\mathrm{e}^{-}\right)+\mathrm{g}-\mathrm{C}_{3} \mathrm{~N}_{4} \\
\mathrm{TiO}_{2}\left(\mathrm{e}^{-}\right)+\text {bias voltage } \rightarrow \mathrm{TiO}_{2}+\text { external circuit } \\
\mathrm{Bi}_{2} \mathrm{O}_{3}\left(\mathrm{e}^{-}\right)+\mathrm{O}_{2} \rightarrow \mathrm{Bi}_{2} \mathrm{O}_{3}+\mathrm{O}_{2} \cdot-
\end{gathered}
$$

Of course, two of these three substances $\left(\mathrm{TiO}_{2}, \mathrm{Bi}_{2} \mathrm{O}_{3}\right.$ and $\mathrm{C}_{3} \mathrm{~N}_{4}$ ) composited together, the electron-holes also could be transferred from high energy band to low energy band. So some other phenomenon, such as electrons transferred from $\mathrm{C}_{3} \mathrm{~N}_{4}$ to $\mathrm{TiO}_{2}$ or from $\mathrm{TiO}_{2}$ to $\mathrm{C}_{3} \mathrm{~N}_{4}$, was described in Fig. 14(b).

\section{Conclusion}

g- $\mathrm{C}_{3} \mathrm{~N}_{4}$ and $\mathrm{Bi}_{2} \mathrm{O}_{3}$ with $\mathrm{TiO}_{2}$-NTs have been coupled into a composite photocatalytic and electrocatalytic material through a sequential dip-coating procedure followed by hightemperature annealing. After adding $\mathrm{g}-\mathrm{C}_{3} \mathrm{~N}_{4}$ and $\mathrm{Bi}_{2} \mathrm{O}_{3}$, in to the host matrix, the absorption spectrum of $\mathrm{g}-\mathrm{C}_{3} \mathrm{~N}_{4} / \mathrm{Bi}_{2} \mathrm{O}_{3} / \mathrm{TiO}_{2}-$ NTs electrode red-shifted in to visible region of electromagnetic spectrum, resulting in an increase in light absorbance. Compared to naked $\mathrm{TiO}_{2}-\mathrm{NTs}$, photocurrent response of g- $\mathrm{C}_{3} \mathrm{~N}_{4}$ / $\mathrm{Bi}_{2} \mathrm{O}_{3} / \mathrm{TiO}_{2}$-NTs was enhanced by 15 times and PEC activity for pollutants degradation was also improved. The enhancement in the PEC and IPCE activities was most likely due to the narrowing of the effective $E_{\mathrm{g}}$ coupled with a positive shift of $E_{\mathrm{fb}}$ (ca. 0.35 $\mathrm{V})$. These results indicated that the $\mathrm{g}-\mathrm{C}_{3} \mathrm{~N}_{4} / \mathrm{Bi}_{2} \mathrm{O}_{3} / \mathrm{TiO}_{2}-\mathrm{NTs}$ composite electrodes have the potential for wastewater treatment during PEC process under visible light irradiation.

\section{Acknowledgements}

This work was financially supported by the National Natural Science Foundation of China (no. 21276235, 21477114). In addition support was provided by the Educational Commission of Zhejiang Province (Y201432049).

\section{References}

1 M. R. Hoffmann, S. T. Martin, W. Y. Choi and D. W. Bahnemann, Chem. Rev., 1995, 95, 69-96.

2 X. B. Chen, S. H. Shen, L. J. Guo and S. S. Mao, Chem. Rev., 2010, 110, 6503-6570.

3 H. Bao, F. F. Li, L. C. Lei, B. Yang and Z. J. Li, RSC Adv., 2014, 4, 27277-27280.

4 A. J. Bard and M. A. Fox, Chem. Res., 1995, 28, 141-145.

5 B. A. Pinaud, J. D. Benck, L. C. Seitz, A. J. Forman, Z. Chen, T. G. Deutsch, B. D. James, K. N. Baum, G. N. Baum,
S. Ardo, H. L. Wang, E. Miller and T. F. Jaramillo, Energy Environ. Sci., 2013, 6, 1983-2002.

6 Q. Liu, D. Wu, Y. Zhou, H. B. Su, R. Wang, C. F. Zhang, S. C. Yan, M. Xiao and Z. G. Zou, ACS Appl. Mater. Interfaces, 2014, 6, 2356-2361.

7 Q. Li, B. D. Guo, J. G. Yu, J. R. Ran, B. H. Zhang, H. J. Yan and J. R. Gong, J. Am. Chem. Soc., 2011, 133, 10878-10884.

8 G. Liu, L. Z. Wang, H. G. Yang, H. M. Cheng and G. Q. Lu, J. Mater. Chem., 2010, 20, 831-843.

9 F. E. Osterloh, Chem. Mater., 2008, 20, 35-54.

10 X. B. Chen, L. Liu, P. Y. Yu and S. S. Mao, Science, 2011, 331, 746-750.

11 H. Yamashita, M. Harada, J. Misaka, M. Takeuchi, K. Ikeue and M. Anpo, J. Photochem. Photobiol. A: Chem., 2002, 148, 257-261.

12 J. C. Yu, G. S. Li, X. C. Wang, X. L. Hu, C. W. Leung and Z. D. Zhang, Chem. Commun., 2006, 25, 2717-2719.

13 C. W. H. Dunnill, Z. A. Aiken, J. Pratten, M. Wilson, D. J. Morgan and I. P. Parkin, J. Photochem. Photobiol. A: Chem., 2009, 207, 244-253.

14 Y. X. Zhao, X. F. Qiu and C. Burda, Chem. Mater., 2008, 20, 2629-2636.

15 Q. Kang, S. H. Liu, L. X. Yang, Q. Y. Cai and C. A. Grimes, ACS Appl. Mater. Interfaces, 2001, 3, 746-749.

16 K. Maeda and K. Domen, J. Phys. Chem. C, 2007, 111, 78517861.

17 K. Mogyorósi, Á. Kmetykó, N. Czirbus, G. Veréb, P. Sipos and A. Dombi, React. Kinet. Catal. Lett., 2009, 98, 215-225.

18 Y. C. Yang, J. W. Wen, J. H. Wei, R. Xiong, J. Shi and C. X. Pan, ACS Appl. Mater. Interfaces, 2013, 5, 6201-6207.

19 Z. H. Zhao, J. Tian, D. Z. Wang, X. L. Kang, Y. H. Sang, H. Liu, J. Y. Wang, S. W. Chen, R. I. Boughton and H. D. Jiang, J. Mater. Chem., 2012, 22, 23395-23403.

20 J. G. Hou, C. Yang, Z. Wang, S. Q. Jiao and H. M. Zhu, Appl. Catal., B, 2013, 129, 333-341.

21 G. T. Yan, M. Zhang, J. Hou and J. J. Yang, Mater. Chem. Phys., 2011, 129, 553-557.

22 X. S. Zhou, B. Jin, S. S. Zhang, H. J. Wang, H. Yu and F. Peng, Electrochem. Commun., 2012, 19, 127-130.

23 X. C. Wang, K. Maeda, A. Thomas, K. Takanabe, G. Xin, J. M. Carlsson, K. Domen and M. Antonietti, Nat. Mater., 2009, 8, 76-82.

24 J. Y. Zhang, Y. H. Wang, J. Jin, J. Zhang, Z. Lin, F. Huang and J. G. Yu, ACS Appl. Mater. Interfaces, 2013, 5, 10317-10324.

25 J. Wang and W. D. Zhang, Electrochim. Acta, 2012, 71, 10-16. 26 X. S. Zhou, B. Jin, L. D. Li, F. Peng, H. J. Wang, H. Yu and Y. P. Fang, J. Mater. Chem., 2012, 22, 17900-17905.

27 S. Shamaila, A. K. L. Sajjad, F. Chen and J. L. Zhang, Appl. Catal., B, 2010, 94, 272-280.

28 Y. Bessekhouad, D. Robert and J.-V. Weber, Catal. Today, 2005, 101, 315-321.

29 Z. F. Bian, J. Zhu, S. H. Wang, Y. Cao, X. F. Qian and H. X. Li, J. Phys. Chem. C, 2008, 112, 6258-6262.

30 Y. J. Cui, Z. X. Ding, P. Liu, M. Antonietti, X. Z. Fu and X. C. Wang, Phys. Chem. Chem. Phys., 2012, 14, 1455-1462.

31 J. L. Hu, H. M. Li, C. J. Huang, M. Liu and X. Q. Qiu, Appl. Catal., B, 2013, 142-143, 598-603. 
32 A. Ghicov, H. Tsuchiya, J. M. Macak and P. Schmuki, Electrochem. Commun., 2005, 7, 505-509.

33 Y. L. Su, S. Han, X. W. Zhang, X. Q. Chen and L. C. Lei, Mater. Chem. Phys., 2008, 110, 239-246.

34 S. S. Zhao, S. Chen, H. T. Yu and X. Quan, Sep. Purif. Technol., 2012, 99, 50-54.

35 K. H. Reddy, S. Martha and K. M. Parida, $R S C A d v .$, 2012, 2, 9423-9436.

36 M. N. Gómez-Cerezo, M. J. Mssũnoz-Batista, D. Tudelab, M. Fernández-García and A. Kubacka, Appl. Catal., B, 2014, 156-157, 307-313.

37 K. Uchida and A. Ayame, Surf. Sci., 1996, 357, 170-178.

38 A. Hameed, T. Montini, V. Gombac and P. Fornasiero, J. Am. Chem. Soc., 2008, 130, 9658-9659.

39 H. M. Zhu, B. F. Yang, J. Xu, Z. P. Fu, M. W. Wen, T. Guo, S. Q. Fu, J. Zuo and S. Y. Zhang, Appl. Catal., B, 2009, 90, 463-469.

40 Y. Zhang, J. N. Lu, X. P. Wang, Q. Xin, Y. Q. Cong, Q. Wang and C. J. Li, J. Colloid Interface Sci., 2013, 409, 104-111.

41 G. P. Dai, J. G. Yu and G. Liu, J. Phys. Chem. C, 2011, 115, 7339-7346.

42 M. A. Butler, J. Appl. Phys., 1977, 48, 1914-1920.

43 S. Kumar, A. G. Fedorov and J. L. Gole, Appl. Catal., B, 2005, 57, 93-107.

44 Z. W. Tong, D. Yang, T. X. Xiao, Y. Tian and Z. Y Jiang, Chem. Eng. J., 2015, 260, 117-125.
45 M. N. Gómez-Cerezoa, M. J. Mũnoz-Batista, D. Tudela, M. Fernández-García and A. Kubacka, Appl. Catal., B, 2014, 156-157, 307-313.

46 W. D. Zhang, L. C. Jiang and J. S. Ye, J. Phys. Chem. C, 2009, 113, 16247-16253.

47 Y. Liu, Y. X. Yu and W. D. Zhang, Electrochim. Acta, 2012, 59, 121-127.

48 S. D. Tilley, M. Cornuz, K. Sivula and M. Gratzel, Angew. Chem., Int. Ed., 2010, 49, 6405-6408.

49 Y. Q. Cong, M. M. Chen, T. Xu, Y. Zhang and Q. Wang, Appl. Catal., B, 2014, 147, 733-740.

50 R. L. Spray, K. J. McDonald and K.-S. Choi, J. Phys. Chem. C, 2011, 115, 3497-3506.

51 Y. Q. Cong, H. S. Park, H. X. Dang, F.-R. F. Fan, A. J. Bard and C. B. Mullins, Chem. Mater., 2012, 24, 579-586.

52 H. Ye, J. Lee, J. S. Jang and A. J. Bard, J. Phys. Chem. C, 2010, 114, 13322-13328.

53 Y. C. Jia, P. Xiao, H. C. He, J. Y. Yao, F. L. Liu, Z. F. Wang and Y. H. Li, Appl. Surf. Sci., 2012, 258, 6627-6631.

54 X. J. Yu, L. Z. Huang, Y. C. Wei, J. Zhang, Z. Z. Zhao, W. Q. Dai and B. H. Yao, Mater. Res. Bull., 2015, 64, 410-417.

55 M. A. Rauf, M. A. Meetani, A. Khaleel and A. Ahmed, Chem. Eng. J., 2010, 157, 373-378.

56 Z. W. Tong, D. Yang, T. X. Xiao, Y. Tian and Z. Y. Jiang, Chem. Eng. J., 2015, 260, 117-125.

57 Y. F. Chen, W. X. Huang, D. L. He, Y. Situ and H. Huang, ACS Appl. Mater. Interfaces, 2014, 6, 14405-14414. 